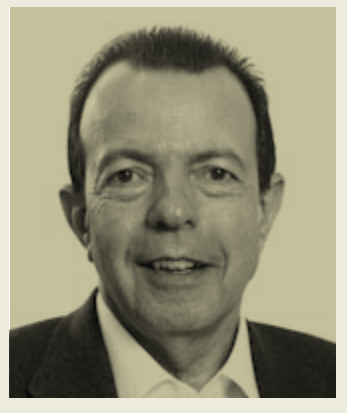

\title{
HOME OFFICE E O MODELO HÍBRIDO DE TRABALHO
}

Com a pandemia da Covid-19, o home office propagou-se muito rapidamente no Brasil. Se considerarmos o universo das empresas presentes no país, poucas tinham experiência, de forma sistematizada, com o trabalho remoto - embora seja válido observar que algumas companhias adotavam essa prática desde 2010.

As empresas que já utilizavam o home office antes da pandemia, na maioria dos casos, são organizações de ponta, de modo que boa parte delas aderiu ao modelo híbrido de trabalho. Ou seja, alguns dias da semana o colaborador trabalha presencialmente e os demais de modo remoto. Com a chegada desse tempo nublado, essas e outras empresas que nunca haviam experimentado o home office passaram, por força das circunstâncias, a fazê-lo de maneira impositiva e em tempo integral.

Embora esteja sendo vivenciado, esse trabalho remoto radical não prevalecerá no pós-pandemia. Tudo leva a crer que boa parte das organizações que já praticavam o home office voltará a adotar o modelo híbrido de trabalho. Isso deve-se por várias razões, entre elas a necessidade de relacionamento mais próximo entre as pessoas. Por mais avançada que possa ser a tecnologia das comunicações, o presencial também é imprescindível na interação entre os profissionais. Por isso, insisto, pelo menos para as gerações atuais, o modelo de trabalho que mescla o presencial e o remoto é o mais apropriado.

Vale ressaltar, entretanto, que no pós-pandemia imediato um número bem reduzido de empresas vai aderir a esse modelo híbrido de trabalho, se levarmos em conta a totalidade de companhias existentes no Brasil. O fato é que o nosso universo corporativo também é composto de uma infinidade de instituições, espalhadas por todos os rincões do país, que não possuem clima comportamental, estrutura organizacional nem tecnologia para adotar o home office como uma de suas modalidades de trabalho.

Tal fato pode ser comprovado e ilustrado por estudos do Instituto de Pesquisa Econômica Aplicada (Ipea), os quais, em junho deste ano, estimavam que havia potencial para o home office alcançar $22,7 \%$ das ocupações nacionais, o que representa mais de 20 milhões de profissionais. No entanto, $\mathrm{o}$ instituto registrou que, no mês de maio, o home office foi praticado por apenas $13,3 \%$ dos trabalhadores ocupados no Brasil - o equivalente a 8,7 milhões de pessoas - e, em julho, por $11,7 \%$, englobando em torno de 7,6 milhões de profissionais. Ou seja, menos de 50\% do número estimado. Esses dados refletem bem nossa realidade corporativa.

A experiência do home office deve ser vista com cautela pelas empresas que aderiram à prática recentemente. Hoje, trata-se de labuta a distância, em contexto de isolamento social, instalada de forma impositiva e, não raro, sem os devidos treinamentos. Acumulou-se com uma série de atividades que surgiram em casa, acrescidas com a tensão da saúde das pessoas e da economia do país. O lazer também foi limitado. Quando tudo isso passar, será o momento de avaliar se o modelo híbrido de trabalho funciona bem ou não para a realidade empresarial em que cada organização está inserida. 